\title{
PLASTICITY INCREASE OF BEECH VENEER BY STEAMING AND GASEOUS AMMONIA TREATMENT
}

\author{
${\text { Václav Šprdlík }{ }^{1, \star}, \text { Martin Brabec }}^{2}$, Stefan Mihailović, ${ }^{1}$ Peter Rademacher ${ }^{2}$
}

\begin{abstract}
Ammonia treatment was used in order to change the colour of wood and also to plasticize the wood before bending or compressing. The mechanism and the process of gaseous ammonia treatment impact on wood are not very well known. The goal of this study was to quantify the effect of gaseous ammonia on mechanical properties, i.e., modulus of elasticity (MOE), modulus of rupture (MOR) and deflection at maximal loading force $\left(\mathrm{y}_{\mathrm{Fmax}}\right)$. When wood was treated by water and ammonia vapour together, significant changes in plasticity of wood were observed. The samples which were firstly exposed to water vapour and then to ammonia vapour exhibit the lowest values of MOE and MOR and an enhanced flexibility of the material. The results show that ammonia treatment increases wood plasticity. This process can be used for manufacturing of bent furniture.
\end{abstract}

Keywords: Fagus sylvatica, mechanical properties, modulus of elasticity, modulus of rupture, plasticization.

\section{INTRODUCTION}

Wood is a natural composite composed of cellulose (35-55\%), hemicelluloses (20-35\%), lignin (20-35\%), and other compounds (3-10\%). Hemicelluloses and lignin as polymer matrices encapsulate cellulose fibres which have a similar function as steel beams reinforcing the concrete matrix. Cellulose represents the crystalline part of wood and mainly gives strength to the wood structure. Lignin and hemicelluloses are amorphous parts that are responsible for wood stiffness. When wood is plasticized by water vapour, ammonia vapour or by boiling in water, the structure of cellulose and lignin changes and the wood becomes more ductile. Ammonia vapour modification under high pressure and high temperature is used during the Lignamon process (Stojčev 1979).

Modification by ammonia has been known since the beginning of the $20^{\text {th }}$ century. The most frequently used techniques are boiling in aqueous ammonia solution or pure ammonia (waterless) and also treatment by gaseous ammonia. A British patent on plasticization effect of ammonia was issued in 1922 (Sparkes 1922). 
Techniques of modification by ammonia are well known; interest in this treatment has recently reappeared (Weigl et al. 2009a, 2009b, 2012; Weigl and Muller 2009; Čermák and Dejmal 2013). The main purpose of this modification is to produce modified wood which imitates the appearance of exclusive dark coloured wood species. This material is often used for furniture and flooring systems. The most often modified wood is European beech (Fagus sylvatica) (Weigl et al. 2012). The ammonia treatment can be combined with mechanical modification as in the manufacturing process of densified wood, commercial named "Lignamon". Lignamon is a manufacturing process which is often used for less strong and durable wood species. After modification, the treated wood can substitute exotic and/ or rare wood species. The production process combines vacuum-pressure impregnation of wood with treatment by ammonia vapour in temperatures of $150-180^{\circ} \mathrm{C}$, plasticisation and densification mainly perpendicular to grain in a press. The process continues with drying and acclimatization (Stojčev 1973).

Ammonia treatment causes changes in the wood chemical as well as anatomical structure. The literature suggests changes in lumen, cell wall deformations, swelling in the middle lamella, primary cell walls and secondary cell walls. Most of the papers focused on mechanical properties, where treatment in aqueous ammonia solution or in pure ammonia was used (Bariska 1969, 1975, Berzin'š 1972, Berzin'š et al. 1970, Stamm 1955). When using gaseous ammonia for the treatment, reduction of wood stiffness and strength is expected. This field is yet to be fully examined. Weigl et al. (2012) observed a significant reduction of modulus of elasticity (MOE), but the reduction of stiffness and modulus of rupture (MOR) is within 6-15\%, which is negligible in common solid wood use. Similar results were shown by Weigl and Müller (2009).

The goal of this paper is to investigate the influence of water vapour, ammonia vapour and the combination of both on bending properties of beech veneers. We want to find out if and how much does the ammonia treatment increases the plasticity of wood. This study is the first step to discover whether ammonia treatment is suitable to increase maximum bending angles in furniture manufacturing and also construction and carpentry.

\section{MATERIALS AND METHODS}

For this experiment, European beech (Fagus sylvatica L.) veneer samples of dimensions $150 \times 40 \times 2,8 \mathrm{~mm}^{3}(\mathrm{~L} \times \mathrm{R} \times \mathrm{T})$ were used. In total, 15 veneers per each type of treatment and the reference series were investigated. The average density of veneers per series is shown in Table 1. Samples were stored under the following conditions: temperature $(\mathrm{T})=23^{\circ} \mathrm{C}$, relative humidity $(\mathrm{RH})=60 \%$ until equilibrium moisture content was reached.

Process times for each type of treatment were adopted from the previous study (Table 1). It was found that the maximum decrease in MOR and stiffness was observed for treatment time $(t)=12 \mathrm{~min}$. The reference series of samples were not modified by any treatment. Samples were steamed in a steam oven using saturated water steam with $\mathrm{T}=100^{\circ} \mathrm{C}$ at atmospheric pressure. Ammonia treatment took place in sealed glass containers, which were placed in a water bath with $\mathrm{T}=100^{\circ} \mathrm{C}$. Every sample was placed on a stainless steel sieve in the glass container. For every sample, $25 \mathrm{ml}$ of ammonia solution with concentration (c) $=25 \%$ was poured in. Heating of the glass container caused ammonia evaporation and increase in the pressure inside the glass container, which accelerated the saturation of the veneers by ammonia. 
Table 1. Treatment conditions and average density per each veneer series.

\begin{tabular}{|c|c|c|c|c|c|}
\hline Type of treatment & Series & $\begin{array}{l}\text { Avg. density } \\
\left(\mathrm{kg} \cdot \mathrm{m}^{-3}\right)\end{array}$ & $\begin{array}{l}\text { Standard } \\
\text { deviation }\end{array}$ & $\begin{array}{l}\text { Time } \\
(\min )\end{array}$ & $\begin{array}{c}\text { Temperature } \\
\left({ }^{\circ} \mathrm{C}\right)\end{array}$ \\
\hline Water vapour & 15 & 647 & 23,3 & 12 & 100 \\
\hline Ammonia vapour & 15 & 633 & 20,1 & 12 & 100 \\
\hline Ammonia + water vapour & 15 & 628 & 25,9 & $12+12$ & 100 \\
\hline Reference samples & 15 & 640 & 17,3 & - & - \\
\hline
\end{tabular}

The measurement of MOR, MOE and the maximum deflection $\left(\mathrm{y}_{\mathrm{Fmax}}\right)$ at the moment when the maximum loading force was applied was performed using the universal testing machine ZWICK Z 050/ TH 3A (Zwick Roell) by the 3-point loading method. The measurement was performed immediately after treatment in plasticized state of the samples. The experiment procedure was set and controlled by TestXpert v. 11.02. The span of supports was $100 \mathrm{~mm}$, the radius of supports and the forcing head was $15 \mathrm{~mm}$. The value of MOR was calculated from the maximum loading force as given in the following equation:

$$
M O R=\frac{3 F_{\max } \times l}{2 b \times h^{2}}
$$

where $F_{\max }$ is the maximum loading force, $l$ is the span of supports, $b$ is the width of sample crosssection, and $h$ is the dimension in the direction of loading.

The calculation of MOE was based on forces measured at $10 \%$ and $40 \%$ of the maximum loading force and the corresponding deflections of the bent veneer measured by the extensometer. The value of MOE was calculated from the following equation:

$$
M O E=\frac{l^{3} x\left(F_{40 \%}-F_{10 \%}\right)}{4 b \times h^{3}\left(u_{40 \%}-u_{10 \%}\right)}
$$

where $F_{40 \%}$ and $F_{10 \%}$ are forces at $40 \%$ and $10 \%$ level of the maximum force $F_{\max }$, and $u_{40 \%}$ and $u_{10 \%}$ are the deflections at forces $F_{40 \%}$ and $F_{10 \%}$.

\section{RESULTS AND DISCUSSION}

Figure 1 and Table 2 shows the differences in MOR for treated and untreated samples. In comparison with the reference samples, the MOR decreased using water vapour and combination of ammonia vapour and water vapour. In case of treatment by ammonia only the effect is opposite - values of MOR increased. The highest decrease in MOR $(-38,7 \%)$ was observed in the case of the combined impact of water and ammonia vapour. According to Weigl and Müller (2009), the average decrease for European beech was $15 \%$. It can be noticed that the increase of values was found using only the gaseous ammonia treatment. Higher efficiency of the plasticization mechanism can be achieved when hydroxyl groups in the wood structure are adsorbed to water molecules from water vapour. Thus ammonia molecules could be connected directly to lignin, cellulose and hemicelluloses and disintegrate $\mathrm{H}$-bonds and Van der Waals forces between these structures; therefore, cohesion between cellulose, lignin and hemicellulose decreases. 


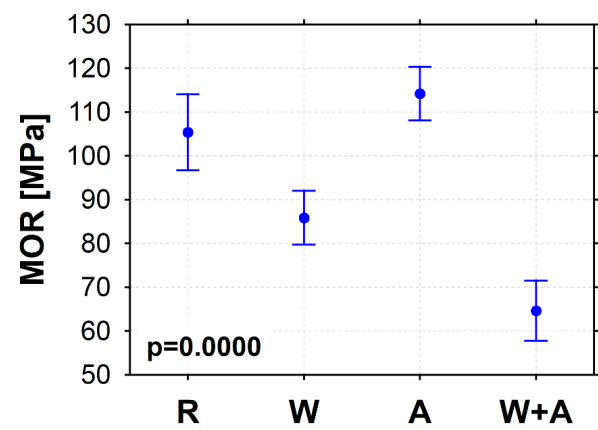

Figure 1. The ANOVA of MOR for treated and reference samples.

Table 2. HSD Tukey test for MOR.

\begin{tabular}{|c|c|c|c|c|}
\hline Treatment & $\begin{array}{c}\{1\} \\
(105,41)\end{array}$ & $\begin{array}{c}\{2\} \\
(85,878)\end{array}$ & $\begin{array}{c}\{3\} \\
(114,24)\end{array}$ & $\begin{array}{c}\{4\} \\
(64,643)\end{array}$ \\
\hline Reference & & 0,004104 & 0,341068 & 0,000162 \\
\hline Water & 0,004104 & & 0,000162 & 0,000437 \\
\hline Ammonia & 0,341068 & 0,000162 & & 0,000162 \\
\hline Water + ammonnia & 0,000162 & 0,000437 & 0,000162 & \\
\hline
\end{tabular}

The differences between MOR, MOE and the maximum deflection $\left(\mathrm{y}_{\mathrm{Fmax}}\right)$ for the three types of treatment and reference samples were evaluated using 1F-ANOVA in combination with HSD Tukey tests. Figure 2 and Table 3 shows the highest decrease in MOE (43,6\% $\rightarrow$ approx. 5GPa) for the samples exposed to the combination of water and ammonia vapour. The thermoplastic behaviour of lignin plays the main role in this process. The water causes swelling of the substrates and increasing the volume of the call wall matrix which in combination with heat results in an increase in void volume around the relaxing segments of the cell wall matrix molecules. This leads to increased molecular mobility of the matrix molecules and macroscopic property of plasticity. Ammonia molecules link to the structure of cellulose, hemicelluloses and lignin in the cell wall and disrupt (hydrogen) H-bonds and Van der Waals forces, bonding the structure of wood. Ammonia treatment may also cause changes in crystallinity, with a partial disintegration of hemicelluloses (Stojčev 1979, Trebula and Klement 2002, Bariska 1969, Besold and Fengel 1983a, Yatsu et al. 1986). Surprisingly, when treated with ammonia vapour only, the decrease in MOE is almost imperceptible (5,4\% $\rightarrow$ approx. $0,6 \mathrm{GPa})$; although the literature reports a significant decrease in MOE, referenced by Bariska (1969), Stojčev (1979), Trebula and Klement (2002). The cause of low efficiency of ammonia treatment could be a shorter time of treatment and also an imperfect seal of the glass containers during the experiment. However, consequent study (Šprdlík et al. 2015) proved significant changes in plasticity of the veneer using pressure impregnation of ammonia. One of the goals of this study was to find method of modification without high pressures and thus increasing the safety and decreasing cost of whole modification. There was also effort to equal times of modification with water vapour and ammonia gas. 


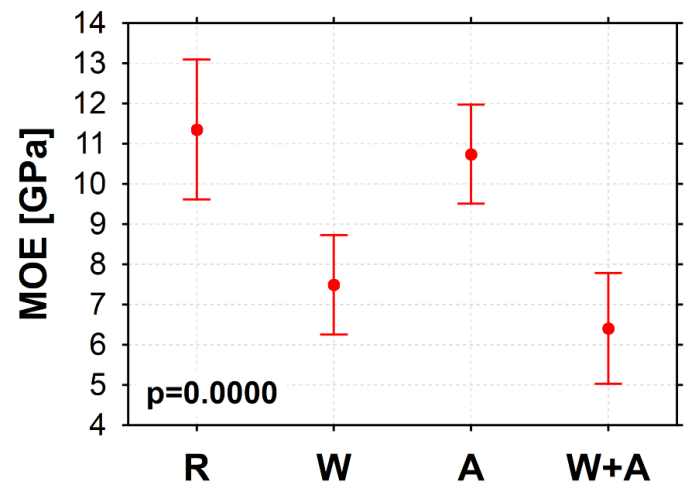

Figure 2. The ANOVA of MOE for treated and reference samples.

Table 3. HSD Tukey test for MOE.

\begin{tabular}{|c|c|c|c|c|}
\hline Treatment & $\{1\}$ & $\{2\}$ & $\{3\}$ & $\begin{array}{c}\{4\} \\
(11,354)\end{array}$ \\
& & 0,004741 & 0,934522 & 0,000607 \\
\hline Reference & & & 0,003582 & 0,631277 \\
\hline Water & 0,004741 & & 0,000383 \\
\hline Ammonia & 0,934522 & 0,003582 & & \\
\hline Water + ammonnia & 0,000607 & 0,631277 & 0,000383 & \\
\hline
\end{tabular}

The results displayed in Figure 3 and Table 4 are closely bonded with MOR and MOE, which determine the stiffness and the values of the maximum deflection $\left(\mathrm{y}_{\mathrm{Fmax}}\right)$ of wood in the plasticized state. This Figure shows manufacturing possibilities of using combination of water and ammonia vapour for bended furniture.

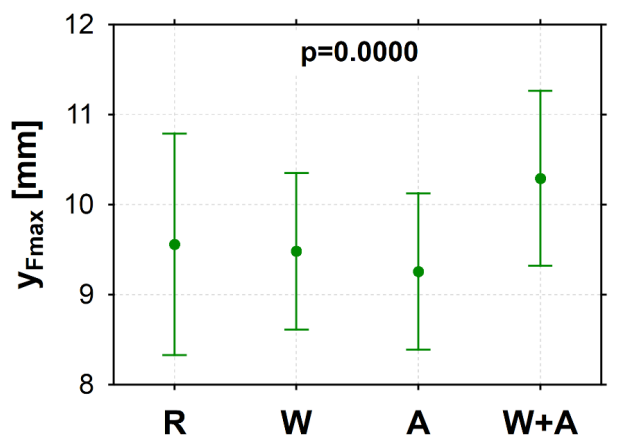

Figure 3. The ANOVA of maximum deflection $\left(\mathrm{y}_{\mathrm{Fmax}}\right)$ changes for treated and untreated samples. 
Table 4. HSD Tukey test for maximum deflection $\left(\mathrm{y}_{\mathrm{Fmax}}\right)$.

\begin{tabular}{|c|c|c|c|c|}
\hline Treatment & $\{1\}$ & $\{2\}$ & $\{3\}$ & $\{4\}$ \\
& $(9,5600)$ & $(9,4820)$ & $(9,2570)$ & $(10,293)$ \\
\hline reference & & 0,999611 & 0,976130 & 0,775267 \\
\hline water & 0,999611 & & 0,981838 & 0,588255 \\
\hline ammonia & 0,976130 & 0,981838 & & 0,381684 \\
\hline
\end{tabular}

The mean load-displacement curves are depicted in Figure 4. Two highest curves correspond to ammonia treated samples and reference samples. These curves exhibit a significant part of elastic deformation. The failure of the sample occurs immediately after the transition to the viscoelastic and plastic deformation. Water vapour treatment and combination of water and ammonia vapours result in a higher proportion of plastic deformation until sample failure. Failure of the material occurs gradually. It leads to the less fragile behaviour of samples treated by water vapour and by the combination of water and ammonia vapour compared to samples treated by gaseous ammonia only and untreated samples which are far more fragile (Weigl at al. 2012, Trebula and Klement 2002).

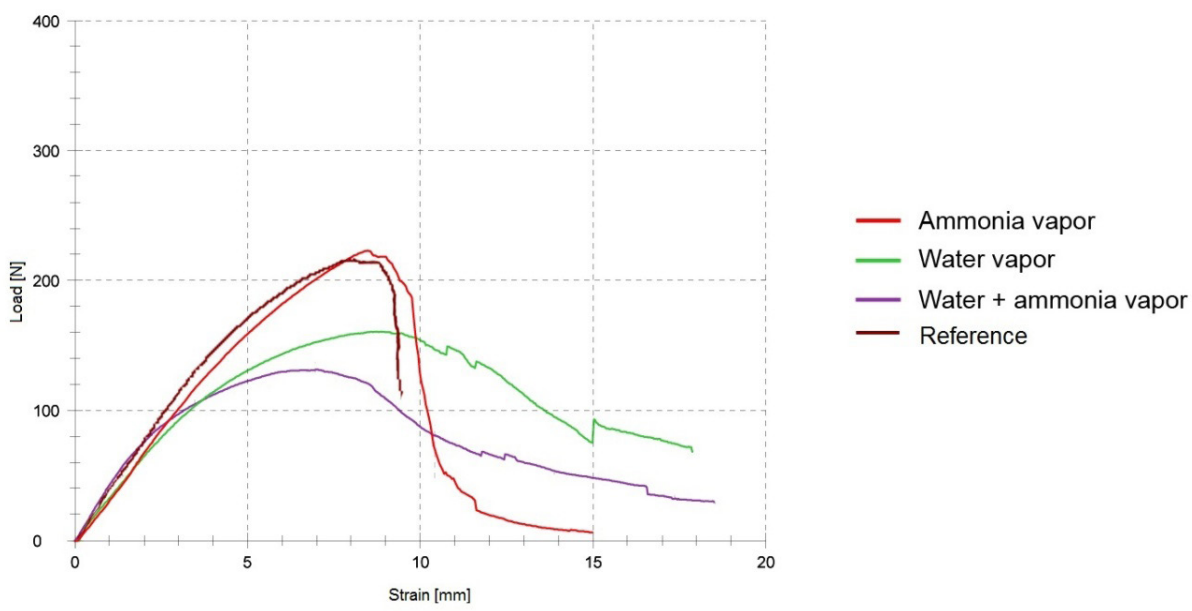

Figure 4. Load-displacement curves of mean values for treated and untreated samples.

\section{CONCLUSIONS}

This study focused on the differences between MOR, MOE and the maximum deflection of veneer at the maximum loading force, when wood modifications by water vapour, ammonia vapour and their combination were applied. 
The samples which were firstly exposed to water vapour and then to ammonia vapour exhibit the highest plasticity. The difference between failures of samples treated by ammonia only and by the combination of water and ammonia vapour was significant. In the former case, the failure appears just after the transition to the viscoelastic and plastic deformation. In the latter case, the failure of sample develops more gradually. When treating the sample only by ammonia vapour there is no significant effect in plasticization.

\section{OUTLOOK}

On the basis of this experiment it was decided to design furniture prototypes. The experiment shows a possible application of ammonia + water vapour treatment in bent furniture design. First examples of chairs, based on ammonia treated veneers, will be produced to prove the practical advantage of this technical process. Veneers are modified by water and ammonia vapour, glued together and pressed in the mould to obtain plywood seats. This modification allows bending of wood with sharper angles than with ordinary beech veneer.

The plan is to use the advantage of Lignamon properties concerning swelling and shrinkage for bathroom furniture design. According to Pařil et al. 2013, the values of swelling and shrinkage of solid Lignamon samples are 50\% less compared to natural beech. The surface of bathroom furniture will be covered by ammonified veneer, which will protect the core of the furniture and will also be more resistant to humidity in the bathroom thanks to the improved swelling and shrinkage behaviour of Lignamon.

\section{ACKNOWLEDGEMENT}

This work was funded by the European Social Fund and the state budget of the Czech Republic, project "The Establishment of an International Research Team for the Development of New Woodbased Materials" reg. no. CZ.1.07/2.3.00/20.0269 (EE2.3.20.0269), and by the Internal Grant Agency (IGA) of the Faculty of Forestry and Wood Technology, Mendel University in Brno (IGA V 79/2013).

\section{REFERENCES}

Bariska, M. 1969. Plastifizierung des Holzes mit Ammoniak in Theorie und Praxis. HolzZentralblatt 5(84):1309-1311.

Bariska, M. 1975. Collapse phenomena in beechwood during and after $\mathrm{NH}_{3}$-impregnation. Wood Sci Technol 9:293-306.

Berzin’̌s, G.; Wagenführ, R.; Steiger, A. 1970. Strukturveränderungen des Holzes beim Plastifizierungsvorgang. Holztechnologie 11(4):233-236.

Berzin’̌s, G. 1972. Holzplastifizierung als Weg zur qualitätserhöhenden Werkstoffsubstitution. Holztechnologie 13(2):103-110.

Besold, G.; Fengel, D. 1983a. Systematische Untersuchungen der Wirkung aggressiver Gase auf Fichtenholz, Teil 2: Veränderungen an den Polysacchariden und am Lignin. Holz Roh-Werkst 41:265269.

Čermák, P.; Dejmal, A. 2013. The effect of heat and ammonia treatment colour response of oak wood (Quercus robur) and comparison of some physical and mechanical properties. Maderas-Ciencia Tecnol 15(3): 375-389. 
Pařil, P.; Brabec, M.; Rousek, R.; Maňák, O.; Rademacher, P.; Čermák, P.; Dejmal, A. 2013. Physical and mechanical properties of densified beech wood plasticized by ammonia. Pro Ligno 9(4):195-202.

Sparkes, M. 1922. Improvements in the Treatment of Wood and in Treated Wood. Patent GB189268 (A). United Kingdom Patent: 30 Nov. 1922. Print.

Stamm, A.J. 1955. Swelling of wood and fiberboards in liquid ammonia. For Prod J 5(6):413-416.

Stojčev, A. 1979. Lignamon - zušlechtěné dřevo: Výroba, vlastnosti a použití. (Lignamon - treated wood: Production, properties and uses), $1^{\text {st }}$ edition. Praha: SNTL - Nakladatelství technické literatury. ISBN 06-099-79.

Šprdlík, V.; Rademacher, P.; Brabec, M.; Rousek, R., Klímová, H.; Mihailović, S. 2015. Beech Veneer Plasticity Change after Steaming and Ammonia Treatment: Case Study - "Limit" Stool. In: HERNÁNDEZ, R; CÁCERES CUADROS, C.(eds). Proceedings of the $22^{\text {nd }}$ International wood machining seminar. $1^{\text {st }}$ issue. 2425, rue de la Terrasse, Quebec City, QC Canada G1V 0A6: Centre de Recherche sur les Matériaux Renouvelables, Université Laval, 2015, p. 183-191. ISBN 978-09947964-0-0.

Trebula, P.; Klement, I. 2002. Sušenie a hydrotermická úprava dreva. (Drying and hydrothermal treatment of wood). $1^{\text {st }}$ edition. Zvolen: Vydavatelstvo TU vo Zvolene. ISBN 80-228-1182-3.

Weigl, M.; Müller, U. 2009. On the mechanical stability of ammonia treated wood. In: Hill CAS, Militz H (eds) $4^{\text {th }}$ European Conference on Wood Modification. 27 $7^{\text {th }}-29^{\text {th }}$ April 2009, Stockholm, Sweden.

Weigl, M.; Kandelbauer, A.; Hansmann, C.; Pöckl, J.; Müller, U.; Grabner, M. 2009a. Application of Natural Dyes in the Coloration of Wood. In: Bechtold T, Mussak R (eds) Handbook of natural colorants. Wiley, New York, pp 277-313.

Weigl, M.; Pöckl, J.; Grabner, M. 2009b. Selected properties of gas phase ammonia treated wood. European Journal of Wood and Wood Products 67:103-109.

Weigl, M.; Müller, U.; Wimmer, R.; Hansmann, C. 2012. Ammonia vs. thermally modified timber-comparison of physical and mechanical properties. European Journal of Wood and Wood Products 70(1-3): 233-239.

Yatsu, L.A.; Calamari, T.A.; Benerito, R.R. 1986. Conversion of cellulose I to stable cellulose III. Tex Res J 56(7):419-424. 